Original article (Orijinal araştırma)

\title{
Investigation of resistance to synthetic pyrethroids in Blattella germanica L., 1767 (Blattodea: Ectobiidae) and Periplaneta americana L., 1758 (Blattodea: Blattidae) populations in Turkey ${ }^{1}$
}

\author{
Türkiye'de Blattella germanica L., 1767 (Blattodea: Ectobiidae) ve Periplaneta \\ americana L., 1758 (Blattodea: Blattidae) popülasyonlarında sentetik piretroidlere karşı \\ direncin araştırılması
}

Emre ÖZ $Z^{2,3^{*}}$
Hüseyin ÇETIN ${ }^{3}$

Atila YANIKOĞLU

\begin{abstract}
Cockroaches are widespread pests found in many houses and other buildings. They are known as a vector of many agents of disease like bacteria, viruses and fungi. The repeated usage of persistent and non-biodegradable insecticides has caused resistance in most of the cockroach populations. In this research, the resistance levels of five Blattella germanica L., 1767 (Blattodea: Ectobiidae) and five Periplaneta americana L., 1758 (Blattodea: Blattidae) cockroach populations against some synthetic pyrethroid insecticides (deltamethrin, permethrin, alpha-cypermethrin and lambda-cyhalothrin) were determined between 2014 and 2018 in Turkey. The resistance tests were performed by the standard glass jar surface method as recommended by World Health Organization. By exposing the test chemicals of the second and third instar nymphs of the cockroaches for $1 \mathrm{~h}$, the median lethal dose $50 \%\left(\mathrm{LD}_{50}\right)$ values, resistance ratios (RR) and resistance status were specified. The $P$. americana populations were all susceptible to tested chemicals with resistance ratios between 1 and 2-fold. In $B$. germanica populations, the toxic effects of tested chemicals were found very low and resistance status was found moderate (RR 7.7-9.0-fold) or high ( $R R \geq 18.5$-fold). This research is the most comprehensive study of the resistance status of the cockroaches in Turkey. In order to prevent the resistance to chemicals, the integrated pest management approach should be prioritized and chemical control should be kept at the lowest level.
\end{abstract}

Keywords: American cockroach, German cockroach, insecticides, nymph, susceptibility

\section{Öz}

Hamam böcekleri birçok ev ve yapılarda bulunan yaygın zararlılardır. Bakteriler, virüsler ve mantarlar gibi pek çok hastalık etkeninin vektörü olarak bilinirler. Kalıcı ve biyolojik olarak parçalanmayan insektisitlerin tekrar tekrar kullanılması, hamam böceği popülasyonlarının çoğunda dirence neden olmuştur. Bu araştırmada, 2014-2018 yılları arasında Türkiye'de beş Blattella germanica L., 1767 (Blattodea: Ectobiidae) ve beş Periplaneta americana L., 1758 (Blattodea: Blattidae) hamam böceği popülasyonunun bazı sentetik piretroid insektisitlere (deltamethrin, permethrin, alpha-cypermethrin ve lambda-cyhalothrin) karşı direnç seviyeleri belirlenmiştir. Direnç testleri Dünya Sağlık Örgütü tarafından önerilen standart cam kavanoz yüzey satıh yöntemi ile yapıımışıı. Hamam böceklerinin ikinci ve üçüncü dönem nimfleri bir saat test kimyasallarına maruz bırakılarak $L_{50}$ değerleri, direnç katsayıları ve direnç durumları belirlendi. Periplaneta americana popülasyonların tamamı test edilen kimyasallara duyarlıydı ve direnç katsayıları 1 ve 2 kat arasındadır. Blattella germanica popülasyonlarında, test edilen kimyasalların toksik etkisi çok düşüktü ve orta (7,7-9,0 kat) ve yüksek direnç ( $\geq 18,5$ kat) bulunmuştur. Bu araştırma hamam böceklerinin direnç durumu hakkında Türkiye'de yapılan en kapsamlı çalışmadır. Kimyasallara karşı direnci önlemek için entegre zararlı mücadele yaklaşımına öncelik verilmeli ve kimyasal kontrol en düşük seviyede tutulmalıdır.

Anahtar sözcükler: Amerikan hamam böceği, Alman hamam böceği, insektisitler, nimf, duyarlıık

\footnotetext{
${ }^{1}$ This study was supported by Akdeniz University, Scientific Research Unit, Antalya, Turkey, Grant Project No: FDK-2015-410.

${ }^{2}$ Antalya Bilim University, Vocational School of Health Services, Department of Medical Services and Techniques, Dialysis Program, 070190, Döşemealtı, Antalya, Turkey

${ }^{3}$ Akdeniz University, Faculty of Science, Department of Biology, 07070, Konyaaltı, Antalya, Turkey

* Corresponding author (Sorumlu yazar) e-mail: emre.oz@antalya.edu.tr

Received (Alınış): 26.04.2021Ａccepted (Kabul ediliş): 18.08.2021 


\section{Introduction}

There are about 4,000 species of cockroaches (Blattodea) most of them are exophilic, feeding on vegetable debris on the forest floor, but approximately 30 species are pests that live in places where people interact each other, such as houses, basements, restaurants and bakeries (WHO, 2006). Cockroaches, one of the most serious public health pests, are mechanical vectors of many disease pathogens like bacteria, viruses and fungi (Fotedar \& Banerjee, 1992; Wahab et al., 2016). Most of these pathogens can survive or persist for a long time on the body surface of cockroaches. Additionally, the feces, saliva and shed body parts of cockroaches may cause allergic reactions, including asthma, sneezing, irritation of eyes and blocked nasal passages reactions in many people (WHO, 2006). For these reasons, it has been necessary to control cockroaches, which are vectors of many agents of disease.

The main groups of insecticides used for cockroach control are organophosphates, carbamates, organochlorines, neonicotinoids and insect growth regulators (chitin synthesis inhibitors and juvenile hormone analogs) (WHO, 2006). Synthetic pyrethroids consist of the major group used in controlling cockroaches and other vectors like mosquitoes, houseflies and ticks in Turkey, which have considerable advantages such as high toxicity to pests, low toxicity to mammals and low persistence in the environment (WHO, 2013). Synthetic pyrethroids are neurotoxic insecticides that alter the properties of the voltage-gated sodium channels in nerve cell membranes and cause the channel to remain open longer (van den Bercken \& Vijverberg, 1988; Silver et al., 2014).

Excessive amounts of pesticides have been used around the world to control cockroaches (Lee et al., 1996). Although the usage of the pesticides against cockroaches gives good results initially, excessive and frequent application of these products has caused resistance in cockroach populations in many regions of the world (Silverman \& Ross, 1994; Lee et al., 1996; Valles \& Strong, 2001; Pai et al., 2005; Chai \& Lee, 2010). In Turkey, there has been limited research on pesticide resistance in cockroaches (Garrett et al., 1968; Erdogan \& Kocak, 1989), and no data on the resistance status of cockroaches to synthetic pyrethroids, except tetramethrin. Since cockroaches have adapted to most insecticides through the development of physiological and behavioral changes and cross -resistance, it is becoming quite difficult to control them. That is why it is necessary to monitor the resistance of field populations for a sustainable cockroach control program.

In this study, resistance to synthetic pyrethroid insecticides (alpha-cypermethrin, deltamethrin, lambda-cyhalothrin, and permethrin) in Blattella germanica L., 1767 (Blattodea: Ectobiidae) and Periplaneta americana L., 1758 (Blattodea: Blattidae) cockroaches collected from Antalya, Turkey were determined. This was the first research in Turkey on resistance to alpha-cypermethrin, deltamethrin, lambda-cyhalothrin and permethrin in $B$. germanica and $P$. americana cockroaches.

\section{Materials and Methods}

\section{Cockroach populations}

Blattella germanica cockroaches were collected from restaurants and bakeries in Güllük (restaurant), Dokuma (bakery), Uncalı (bakery), Ahatlı (restaurant) and Lara (restaurant), and P. americana cockroaches were collected from manholes and basements in Toros (basement), 100. Yll (manhole), Dokuma (manhole), Ahatlı (manhole), Arapsuyu (manhole) in Antalya, Turkey between April and September 2014 (Tables 1-8). There was at least $2 \mathrm{~km}$ between the locations where the specimens were collected. Even though control with $P$. americana has been regularly conducted by the Pest Control Department of Antalya Metropolitan Municipality for more than 10 years with synthetic pyrethroids insecticides were applied at 13 months intervals, control of $B$. germanica has been done by public and pest control applicators 2-4 weeks intervals. Cockroaches were cultured by providing cat food and water ad libitum at $25 \pm 2^{\circ} \mathrm{C}$ and $60 \pm 10 \%$ $\mathrm{RH}$ with a 12:12 h L:D photoperiod. Ootheca (egg capsules) obtained from adult cockroaches were hatched 
in about 3-4 months. To obtain enough individuals of second and third instar nymphs, they have been cultured for 12-18 days under laboratory conditions. Bioassays were performed when the hatchlings reached the second and third stage nymphs in the first generation. An insecticide-susceptible population of B. germanica were obtained from Hacettepe University, Pesticide Test Laboratory, Ankara, Turkey in 2008. As there was no insecticide-susceptible population of $P$. americana in our laboratory, the population which had the lowest $L D_{50}$ value was considered a susceptible population.

\section{Chemicals}

Four synthetic pyrethroid insecticides used in this research were alpha-cypermethrin (purity 98.69\%), deltamethrin (purity 96\%), lambda-cyhalothrin (purity 95\%), and permethrin (purity 93\%), which were purchased Sigma-Aldrich (Chemie GmbH Riedstrasse 2 D-89555 Steinheim Company). These tested chemicals are the most common insecticides used in pest management and, in Turkey, are applied as residual sprays. Analytical acetone was used as a solvent of tested insecticides and control.

\section{Resistance Tests}

Resistance tests were performed using the standard glass jar surface method recommended by World Health Organization (WHO, 1981) in Akdeniz University Vector Ecology and Control Laboratory between 2014-2018. Stock solutions of each chemical were prepared in acetone for the tests. From these solutions, according to the application dose $\left(\mathrm{g}\right.$ ai/ $\left./ \mathrm{m}^{2}\right), 1 \mathrm{ml}$ of the solutions were applied to the surface of the jars. The jars were then rotated horizontally until the acetone vaporized, so that the insecticide completely covered the inner surface of the jars. For the control group, only acetone was applied. After $24 \mathrm{~h}, 10$ second and third instar nymphs of cockroaches were released to jars and exposed to insecticides for $1 \mathrm{~h}$. After 1-h exposure, nymphs were transferred to clean jars $(250 \mathrm{ml})$ provided a cotton ball saturated with water. Ten mixed individuals from both second and third instar nymphs of cockroaches were used for each replicate (according to preliminary studies, there is no difference between stages in terms of mortality rates). Four replicates were used for each tested dose and control group. At least five application doses that caused $\geq 0 \%$ and $\leq 100 \%$ mortality were used for the determination of $L D_{50}$ values in the trials. Mortality was recorded after $24 \mathrm{~h}$. A cockroach was considered dead if it was unable to reach its normal position after touching the abdomen with forceps.

\section{Data analysis}

$\mathrm{LD}_{50}$ values were calculated by the StatPlus probit analysis program. Resistance ratios (RR) were calculated by dividing $L D_{50}$ values of the field populations by the $L_{50}$ value of the susceptible population. Resistance levels were classified based on the standard of Lee et al. (1999): RR <2-fold, very little or no resistance; $R R=2-5$-fold, low resistance; $R R=5-10$-fold, moderate resistance; and $R R>10$, high resistance.

\section{Results}

According to the results, the tested chemicals were highly toxic to $P$. americana, resulting in a mortality of $\geq 95 \%$ at the $\mathrm{WHO}$ recommended doses. Therefore, we had to use lower doses than recommended by WHO. LD 50 values were $0.0001 \mathrm{~g}$ ai $/ \mathrm{m}^{2}$ for deltamethrin, $0.0002-0.0003 \mathrm{~g}$ ai $/ \mathrm{m}^{2}$ for alphacypermethrin, $0.0001-0.0002 \mathrm{~g}$ ai $/ \mathrm{m}^{2}$ for lambda-cyhalothrin and 0.0006-0.0011 g ai $/ \mathrm{m}^{2}$ for permethrin (Tables 1-4). Resistance ratios of all the populations were 1-2-fold, so all populations were classified as having no resistance, very low resistance or low resistance. 
Investigation of resistance to synthetic pyrethroids in Blattella germanica L., 1767 (Blattodea: Ectobiidae) and Periplaneta americana L., 1758 (Blattodea: Blattidae) populations in Turkey

Table 1. $L D_{50}$ values, $\mathrm{LD}_{50}$ (min-max), resistance ratios and resistance status of Periplaneta americana nymphs to alpha-cypermethrin

\begin{tabular}{|c|c|c|c|c|c|c|c|}
\hline Population & $n$ & $\begin{array}{c}\mathrm{LD}_{50}\left(\mathrm{~g} \text { ai } / \mathrm{m}^{2}\right) \\
\text { min-max }\end{array}$ & $\begin{array}{c}\mathrm{LD}_{50} \\
\left(\mathrm{~g} \mathrm{ai} / \mathrm{m}^{2}\right)\end{array}$ & $\begin{array}{l}\text { Resistance } \\
\text { ratio }\end{array}$ & Resistance status & $x^{2}(d f)$ & Slope (SE) \\
\hline Arapsuyu & 320 & $0.0002-0.0005$ & 0.0003 & 1.5 & $\begin{array}{c}\text { No resistance or } \\
\text { very low resistance }\end{array}$ & $11.1(3)$ & $2.39(0.52)$ \\
\hline Toros & 320 & $0.0002-0.0002$ & 0.0002 & 1.0 & $\begin{array}{l}\text { No resistance or } \\
\text { very low resistance }\end{array}$ & $11.1(3)$ & $3.60(0.30)$ \\
\hline Ahatlı & 320 & $0.0002-0.0003$ & 0.0003 & 1.5 & $\begin{array}{c}\text { No resistance or } \\
\text { very low resistance }\end{array}$ & $11.1(3)$ & $3.46(0.27)$ \\
\hline Dokuma & 320 & $0.0002-0.0003$ & 0.0002 & 1.0 & $\begin{array}{l}\text { No resistance or } \\
\text { very low resistance }\end{array}$ & $11.1(3)$ & $3.17(0.26)$ \\
\hline 100. YII & 320 & $0.0002-0.0004$ & 0.0003 & 1.5 & $\begin{array}{l}\text { No resistance or } \\
\text { very low resistance }\end{array}$ & $11.1(3)$ & $2.70(0.40)$ \\
\hline
\end{tabular}

Table 2. $\mathrm{LD}_{50}$ values, $\mathrm{LD}_{50}$ (min-max), resistance ratios and resistance status of Periplaneta americana nymphs to deltamethrin

\begin{tabular}{|c|c|c|c|c|c|c|c|}
\hline Population & $\mathrm{n}$ & $\begin{array}{c}\mathrm{LD}_{50}\left(\mathrm{~g} \text { ai } / \mathrm{m}^{2}\right) \\
\min -\mathrm{max}\end{array}$ & $\begin{array}{c}\mathrm{LD}_{50} \\
\left(\mathrm{~g} \mathrm{ai} / \mathrm{m}^{2}\right)\end{array}$ & $\begin{array}{l}\text { Resistance } \\
\text { ratio }\end{array}$ & Resistance status & $x^{2}(d f)$ & Slope (SE) \\
\hline Arapsuyu & 240 & $0.0001-0.0001$ & 0.0001 & 1 & $\begin{array}{c}\text { No resistance or } \\
\text { very low resistance }\end{array}$ & $7.82(3)$ & $4.10(0.33)$ \\
\hline Toros & 240 & $0.0001-0.0006$ & 0.0001 & 1 & $\begin{array}{l}\text { No resistance or } \\
\text { very low resistance }\end{array}$ & $7.82(3)$ & $1.96(0.47)$ \\
\hline Ahatlı & 240 & $0.0001-0.0003$ & 0.0001 & 1 & $\begin{array}{c}\text { No resistance or } \\
\text { very low resistance }\end{array}$ & $7.82(3)$ & $2.76(0.63)$ \\
\hline Dokuma & 240 & $0.0001-0.0002$ & 0.0001 & 1 & $\begin{array}{l}\text { No resistance or } \\
\text { very low resistance }\end{array}$ & $7.82(3)$ & $2.75(0.42)$ \\
\hline 100. YII & 240 & $0.0001-0.0002$ & 0.0001 & 1 & $\begin{array}{c}\text { No resistance or } \\
\text { very low resistance }\end{array}$ & $7.82(3)$ & $2.29(0.24)$ \\
\hline
\end{tabular}

Table 3. $\mathrm{LD}_{50}$ values, $\mathrm{LD}_{50}$ (min-max), resistance ratios and resistance status of Periplaneta americana nymphs to lambda-cyhalothrin

\begin{tabular}{lccccccc}
\hline Population & $\mathrm{n}$ & $\begin{array}{c}\mathrm{LD}_{50}\left(\mathrm{~g} \mathrm{ai} / \mathrm{m}^{2}\right) \\
\mathrm{min}-\mathrm{max}\end{array}$ & $\begin{array}{c}\mathrm{LD}_{50} \\
\left(\mathrm{~g} \mathrm{ai} / \mathrm{m}^{2}\right)\end{array}$ & $\begin{array}{c}\text { Resistance } \\
\text { ratio }\end{array}$ & Resistance status & $\mathrm{X}^{2}(\mathrm{df})$ & Slope $(\mathrm{SE})$ \\
\hline Arapsuyu & 280 & $0.0001-0.0002$ & 0.0002 & 2 & Low resistance & $9.49(3)$ & $4.51(0.79)$ \\
Toros & 280 & $0.0001-0.0002$ & 0.0002 & 2 & Low resistance & $9.49(3)$ & $4.32(0.77)$ \\
Ahatlı & 280 & $0.0001-0.0001$ & 0.0001 & 1 & $\begin{array}{c}\text { No resistance or } \\
\text { very low resistance }\end{array}$ & $9.49(3)$ & $3.70(0.54)$ \\
Dokuma & 280 & $0.0001-0.0001$ & 0.0001 & 1 & $\begin{array}{c}\text { No resistance or } \\
\text { very low resistance }\end{array}$ & $9.49(3)$ & $3.81(0.31)$ \\
100. YIl & 280 & $0.0001-0.0002$ & 0.0002 & 2 & Low resistance & $9.49(3)$ & $4.71(0.49)$ \\
\hline
\end{tabular}

Table 4. $\mathrm{LD}_{50}$ values, $\mathrm{LD}_{50}$ (min-max), resistance ratios and resistance status of Periplaneta americana nymphs to permethrin

\begin{tabular}{|c|c|c|c|c|c|c|c|}
\hline Population & $\mathrm{n}$ & $\begin{array}{c}\mathrm{LD}_{50}\left(\mathrm{~g} \mathrm{ai} / \mathrm{m}^{2}\right) \\
\min -\mathrm{max}\end{array}$ & $\begin{array}{c}\mathrm{LD}_{50} \\
\left(\mathrm{~g} \mathrm{ai} / \mathrm{m}^{2}\right)\end{array}$ & $\begin{array}{l}\text { Resistance } \\
\text { ratio }\end{array}$ & Resistance status & $x^{2}(d f)$ & Slope (SE) \\
\hline Arapsuyu & 320 & 0.0004-0.0009 & 0.0006 & 1.00 & $\begin{array}{c}\text { No resistance or } \\
\text { very low resistance }\end{array}$ & $11.1(3)$ & $3.71(0.61)$ \\
\hline Toros & 320 & $0.0006-0.0012$ & 0.0009 & 1.50 & $\begin{array}{c}\text { No resistance or } \\
\text { very low resistance }\end{array}$ & $11.1(3)$ & $1.65(0.19)$ \\
\hline Ahatlı & 320 & $0.0008-0.0010$ & 0.0009 & 1.50 & $\begin{array}{l}\text { No resistance or } \\
\text { very low resistance }\end{array}$ & $11.1(3)$ & $1.85(0.61)$ \\
\hline Dokuma & 320 & $0.0001-0.0043$ & 0.0007 & 1.17 & $\begin{array}{c}\text { No resistance or } \\
\text { very low resistance }\end{array}$ & $11.1(3)$ & $1.23(0.52)$ \\
\hline 100. YII & 320 & $0.0003-0.0043$ & 0.0011 & 1.83 & $\begin{array}{c}\text { No resistance or } \\
\text { very low resistance }\end{array}$ & $11.1(3)$ & $2.08(1.04)$ \\
\hline
\end{tabular}

In field B. germanica populations, the toxicity of the tested chemicals was very low to moderate ( 0 to $80 \%$ mortality), although the WHO recommended doses of the tested chemicals were generally assessed as highly toxic $(\geq 96.7 \%$ mortality) on the susceptible population. Higher application doses than recommended by $\mathrm{WHO}$ were used to calculate $\mathrm{LD}_{50}$ values.

Alpha-cypermethrin gave between 0 and $50 \%$ mortality at the WHO recommended doses $(0.024$ and $\left.0.048 \mathrm{~g} \mathrm{ai} / \mathrm{m}^{2}\right)$ in field-collected populations although $100 \%$ mortality was shown in the susceptible 
population at these doses. $L D_{50}$ were $0.0002 \mathrm{~g} \mathrm{ai} / \mathrm{m}^{2}$ for the susceptible population and between 0.109 $13.4 \mathrm{~g} \mathrm{ai} / \mathrm{m}^{2}$ for field-collected populations. When evaluated according to the resistance ratios, high resistance ratios ( $\geq 545$-fold) were observed in all populations (Table 5 ).

Table 5. $\mathrm{LD}_{50}$ values, $\mathrm{LD}_{50}$ (min-max), resistance ratios and resistance status of Blattella germanica nymphs to alpha-cypermethrin

\begin{tabular}{lccccccc}
\hline Population & $\mathrm{n}$ & $\begin{array}{c}\mathrm{LD}_{50}\left(\mathrm{~g} \mathrm{ai} / \mathrm{m}^{2}\right) \\
\mathrm{min}-\mathrm{max}\end{array}$ & $\begin{array}{c}\mathrm{LD}_{50} \\
\left(\mathrm{~g} \mathrm{ai} / \mathrm{m}^{2}\right)\end{array}$ & $\begin{array}{c}\text { Resistance } \\
\text { ratio }\end{array}$ & Resistance status & $\mathrm{X}^{2}(\mathrm{df})$ & Slope (SE) \\
\hline WHO & 240 & $0.0001-0.0002$ & 0.0002 & & & $7.82(3)$ & $4.56(0.51)$ \\
Uncalı & 360 & $3.42-46.40$ & 12.60 & $\geq 1000$ & High & $12.6(3)$ & $2.26(1.02)$ \\
Ahatı & 360 & $4.54-10.70$ & 7.59 & $\geq 1000$ & High & $9.49(3)$ & $0.35(0.11)$ \\
Dokuma & 360 & $2.27-78.50$ & 13.40 & $\geq 1000$ & High & $12.6(3)$ & $1.90(0.86)$ \\
Lara & 360 & $1.40-4.19$ & 2.27 & $\geq 1000$ & High & $9.49(3)$ & $0.56(0.06)$ \\
Güllük & 360 & $0.0057-2.09$ & 0.11 & 545 & High & $7.82(3)$ & $0.65(0.25)$ \\
\hline
\end{tabular}

Deltamethrin had very low toxicity $(\leq 5 \%)$ to all populations at the WHO recommended dose $\left(0.024 \mathrm{~g} \mathrm{ai} / \mathrm{m}^{2}\right)$ but $96.7 \%$ mortality in the susceptible population at the same dose. $L D_{50}$ value was $0.0004 \mathrm{~g} \mathrm{ai} / \mathrm{m}^{2}$ for the susceptible population. All of the populations were in the high resistance category ( $\geq 1000$-fold) (Table 6).

Table 6. $\mathrm{LD}_{50}$ values, $\mathrm{LD}_{50}$ (min-max), resistance ratios and resistance status of Blattella germanica nymphs to deltamethrin

\begin{tabular}{lccccccc}
\hline Population & $\mathrm{n}$ & $\begin{array}{c}\mathrm{LD}_{50}\left(\mathrm{~g} \mathrm{ai} / \mathrm{m}^{2}\right) \\
\mathrm{min}-\mathrm{max}\end{array}$ & $\begin{array}{c}\mathrm{LD}_{50} \\
\left(\mathrm{~g} \mathrm{ai} / \mathrm{m}^{2}\right)\end{array}$ & $\begin{array}{c}\text { Resistance } \\
\text { ratio }\end{array}$ & Resistance status & $\mathrm{x}^{2}(\mathrm{df})$ & Slope (SE) \\
\hline WHO & 240 & $0.0001-0.0037$ & 0.0004 & & & $7.82(3)$ & $1.51(0.98)$ \\
Uncalı & 240 & $1.00-78.4 \times 10^{12}$ & $54.8 \times 10^{3}$ & $\geq 1000$ & High & $7.82(3)$ & $0.36(0.41)$ \\
Ahatlı & 240 & $0.0046-6.54 \times 10^{9}$ & $5.51 \times 10^{3}$ & $\geq 1000$ & High & $7.82(3)$ & $0.34(0.17)$ \\
Dokuma & 240 & $973-119 \times 10^{12}$ & $225 \times 10^{3}$ & $\geq 1000$ & High & $7.82(3)$ & $0.28(0.13)$ \\
Lara & 240 & $0.160-11.1 \times 10^{6}$ & $1.33 \times 10^{3}$ & $\geq 1000$ & High & $7.82(3)$ & $0.44(0.18)$ \\
Güllük & 240 & $0.412-677$ & 16.7 & $\geq 1000$ & High & $7.82(3)$ & $0.43(0.14)$ \\
\hline
\end{tabular}

Lambda-cyhalothrin demonstrated a very low toxic effect $(\leq 10 \%)$ on populations of Uncalı and Dokuma at the WHO recommended doses $\left(0.012\right.$ and $\left.0.024 \mathrm{~g} \mathrm{ai} / \mathrm{m}^{2}\right)$, while high mortality (100 and $\left.92.5 \%\right)$ to populations of Ahatlı and Güllük, respectively, at $0.024 \mathrm{~g} \mathrm{ai} / \mathrm{m}^{2}$. LD50 was $0.0027 \mathrm{~g} \mathrm{ai} / \mathrm{m}^{2}$ for the Güllük population, and this population was categorized as having moderate resistance $(9.0$-fold). According to the resistance ratios, the other populations were in the high resistance category ( $\geq 34.7$-fold) (Table 7 ).

Table 7. $\mathrm{LD}_{50}$ values, $\mathrm{LD}_{50}$ (min-max), resistance ratios and resistance status of Blattella germanica nymphs to lambda-cyhalothrin

\begin{tabular}{|c|c|c|c|c|c|c|c|}
\hline Population & $\mathrm{n}$ & $\begin{array}{c}\mathrm{LD}_{50}\left(\mathrm{~g} \mathrm{ai} / \mathrm{m}^{2}\right) \\
\min -\max \end{array}$ & $\begin{array}{c}\mathrm{LD}_{50} \\
\left(\mathrm{~g} \mathrm{ai} / \mathrm{m}^{2}\right)\end{array}$ & $\begin{array}{c}\text { Resistance } \\
\text { ratio }\end{array}$ & Resistance status & $X^{2}(d f)$ & Slope (SE) \\
\hline WHO & 320 & $0.0001-0.0006$ & 0.0003 & & & $7.82(3)$ & $1.65(0.28)$ \\
\hline Uncalı & 400 & $1.78-1.50 \times 10^{3}$ & 5.13 & $\geq 1000$ & High & $7.82(3)$ & $1.31(0.35)$ \\
\hline Ahatlı & 400 & $0.0075-0.0919$ & 0.0209 & 69.7 & High & $11.1(3)$ & $1.23(0.25)$ \\
\hline Dokuma & 400 & $2.98-2.37 \times 10^{3}$ & 20.7 & $\geq 1000$ & High & $9.49(3)$ & $0.51(0.09)$ \\
\hline Lara & 400 & $0.0068-0.0176$ & 0.0104 & 34.7 & High & $9.49(3)$ & $1.87(0.27)$ \\
\hline Güllük & 400 & $0.0008-0.0051$ & 0.0027 & 9.0 & Moderate & $9.49(3)$ & $2.04(0.48)$ \\
\hline
\end{tabular}

Permethrin gave low mortality (between 0 and 42.5\%) in Uncalı, Dokuma, Lara, and Ahatlı populations at the WHO recommended doses $\left(0.1\right.$ and $\left.0.2 \mathrm{~g} \mathrm{ai} / \mathrm{m}^{2}\right)$. When evaluated according to the resistance ratios, high resistance $(\geq 18.5$-fold) was observed at all the populations except the Güllük population that has moderate resistance (7.7-fold) (Table 8$)$. 
Investigation of resistance to synthetic pyrethroids in Blattella germanica L., 1767 (Blattodea: Ectobiidae) and Periplaneta americana L., 1758 (Blattodea: Blattidae) populations in Turkey

Table 8. $L_{50}$ values, $L_{50}$ (min-max), resistance ratios and resistance status of Blattella germanica nymphs to permethrin

\begin{tabular}{lccccccc}
\hline Population & $\mathrm{n}$ & $\begin{array}{c}\mathrm{LD}_{50}\left(\mathrm{~g} \mathrm{ai} / \mathrm{m}^{2}\right) \\
\mathrm{min}-\mathrm{max}\end{array}$ & $\begin{array}{c}\mathrm{LD}_{50} \\
\left(\mathrm{~g} \mathrm{ai} / \mathrm{m}^{2}\right)\end{array}$ & $\begin{array}{c}\text { Resistance } \\
\text { ratio }\end{array}$ & Resistance status & $\mathrm{x}^{2}(\mathrm{df})$ & Slope $(\mathrm{SE})$ \\
\hline WHO & 240 & $0.0121-0.0177$ & 0.0148 & & & $7.82(3)$ & $2.50(0.22)$ \\
Uncalı & 360 & $13.5-133$ & 31.2 & $\geq 1000$ & High & $9.49(3)$ & $0.53(0.08)$ \\
Ahatlı & 360 & $0.0441-1.66$ & 0.273 & 18.5 & High & $7.82(3)$ & $1.69(0.43)$ \\
Dokuma & 360 & $37.0-984$ & 109 & $\geq 1000$ & High & $9.49(3)$ & $0.70(0.13)$ \\
Lara & 360 & $0.312-0.598$ & 0.426 & 28.8 & High & $11.1(3)$ & $2.43(0.24)$ \\
Güllük & 360 & $0.0774-0.170$ & 0.114 & 7.7 & Moderate & $7.82(3)$ & $2.99(0.48)$ \\
\hline
\end{tabular}

\section{Discussion}

In recent years, large quantities of chemical pesticides have been used to control agriculture, forest and public health pests. Although successful pest control is achieved, resistance to insecticides, which is a result of genetic selection, has become a major problem. According to various studies, many pest species developed resistance to insecticides including pyrethroids, carbamates, microbials and insect growth regulators (Brogdon \& McAllister, 1998; Cetin et al., 2019; Ser \& Cetin, 2019; Erdogan \& Cetin, 2020).

In this research, all of the $P$. americana populations were very susceptible to the tested chemicals and had no resistance, very low resistance or low resistance. In the literature there are few studies on the resistance of $P$. americana. Syed et al. (2014) investigated the insecticidal efficacy of four insecticides including deltamethrin on three $P$. americana populations collected from Pakistan and reported that the the LC 50 were 2.07, 2.50 and $4.15 \mu \mathrm{l} / \mathrm{ml}$, and resistance ratios were 1.21-2-fold for deltamethrin. Kawther et al. (2013) investigated the toxicity of permethrin on P. americana and reported that the $\mathrm{LC}_{50}$ was $2.217 \mathrm{mg} / \mathrm{l}$, and the high toxicity for permethrin was shown at $0.1 \mathrm{mg} / \mathrm{l}$ whereas low toxicity of permethrin was recorded at $0.000001 \mathrm{mg} / \mathrm{l}$. Also, Doroudgar et al. (1998) studied the toxicity of a commercial product containing permethrin and reported resistance ratios of 1.64-3.04-fold, which was classified as susceptible as in our research. Azza et al. (2010) studied susceptibility of $P$. americana collected from Wad Medani (Sudan Gezira) to lambda-cyhalothrin and deltamethrin, and found that adult $P$. americana populations had acceptable levels of susceptibility to all the tested insecticides ( LC $_{50} 0.02$ and $0.04 \mu \mathrm{g} /$ individual, respectively).

The absence of selection pressure may be the main reason for the low resistance levels and low $\mathrm{LD}_{50}$ of $P$. americana populations tested in Antalya, Turkey. According to another study, Strong et al. (1997) monitored the level of cypermethrin resistance and found that the $\mathrm{LC}_{50}$ value of the selected $\mathrm{F}_{6}$ generation adults was elevated 3-fold compared with the parent generation. The Pest Control Department of Antalya Metropolitan Municipality was consulted to obtain information about the history of the control of $P$. americana. The control with $P$. americana has been regularly undertaken for more than 10 years by with the help from pest control experts, and synthetic pyrethroids insecticides were applied in rotation (personal communication). If the environment in the residential houses is not particularly humid, $P$. americana does not normally infest these housed. For this reason, biocidal pesticides are not often used often by pest control applicators. As a result, the resistance is considered less in $P$. americana because the selection pressure on $P$. americana is much less than on $B$. germanica.

Another reason may be related to the annual number of generations of American cockroaches. Periplaneta americana has only one generation per year whereas $B$. germanica has three to four generations per year. At $25^{\circ} \mathrm{C}$, the longevity of the $B$. germanica ranged from 95 and 142 days, and each female may deposit 4-9 oothecae with an average of 38 eggs each. These characteristics facilitate the development of resistance to insecticides (Mallis, 1990). 
While American cockroaches were found to be sensitive to the application doses recommended by the World Health Organization and the Ministry of Health, less than $80 \%$ mortality was detected in German cockroaches. According to our survey, there was no resistance study to the alpha-cypermethrin on $B$. germanica.

Many studies have demonstrated that the most of $B$. germanica populations have developed some resistance to deltamethrin (Diaz Pantoja et al., 2000; Wei et al., 2001; Chang et al., 2010). Chai \& Lee (2010) studied the resistance levels of $B$. germanica collected from 22 different localities of Singapore and found low to very high resistance for deltamethrin (4.5 to 468 -fold). Jang et al. (2017) picked up the $B$. germanica from a restaurant in the Republic of Korea and found that female cockroaches have 450-fold resistance (extremely high levels of resistance) for deltamethrin. Hu et al. (2020) studied the resistance levels of 24 populations of $B$. germanica collected from in Taiwan and reported that the deltamethrin resistance ratio of 1.5 to 817.5 -fold.

Resistance to lambda-cyhalothrin has been reported in many populations in different countries. Valles (1999) studied resistance levels of 13 field-collected populations of $B$. germanica for lambdacyhalothrin, and found that the resistance levels from 21 to 67 -fold using a topical insecticide bioassay and 12.9 to 15.6-fold using the residue jar bioassay. Diaz Pantoja et al. (2000) studied that the toxicities for the 9 populations of the $B$. germanica measured by topical application, and a test with lambda-cyhalothrin indicated that nearly $50 \%$ of the populations had $R R>30$.

Moderate or high resistance to permethrin has been observed in many populations worldwide (Ladonni, 2001; Wei et al., 2001; Chang et al., 2010; Gondhalekar et al., 2011). Nasirian et al. (2006) studied the susceptibility of eleven populations of $B$. germanica collected from nine infested student dormitories and two infested hospitals in Tehran, Iran to permethrin. They reported that the two populations had moderate resistance (8.6-9.8-fold) and the rest were highly resistant (10.5 to 17.7-fold). Limoee et al. (2012) reported that two hospital-collected populations of the $B$. germanica have low and moderate resistance ( 3.15 and 3.36 -fold) to permethrin. The low resistance was attributed to the fact that the populations were not exposed to the permethrin for at least a few generations. Jang et al. (2017) found 569 -fold resistance ratio $\left(\mathrm{LD}_{50} 3.64 \mu \mathrm{g} /\right.$ individual) to permethrin in female $B$. germanica collected from a restaurant in the Republic of Korea.

Globally there have been many resistance and toxicity studies on $B$. germanica but only limited research has been done in Turkey. Garrett et al. (1968) reported that $B$. germanica collected from İzmir was resistant to dieldrin. Erdogan \& Kocak (1989) reported that an Ankara population of $B$. germanica had 9.2-11.2-fold resistance to Sumithion and tetramethrin.

The high resistance was demonstrated in nearly all $B$. germanica populations in our experiments. These results reveal that resistant populations were not isolated and can be found in all parts of the city. Blattella germanica disturbs people because it is of constantly active in environments such as homes, restaurants, and bakeries. For this reason, pest control applicators have used insecticides extensively against $B$. germanica for many years. Some bad practices (e.g., not using the appropriate dose or repeated use of the same active substance) may increase the number of surviving resistant individuals, which is thought to increase the level of resistance in B. germanica.

Higher resistance was found in Uncalı and Dokuma populations (collected from bakeries) compared to Ahatlı, Lara and Güllük populations (collected from restaurants). The reason for this situation could be that the cockroach populations might have been much more exposed to insecticides due to the more frequent inspections of bakeries. Therefore, it is thought that individuals that survive after insecticide application may increase the resistance by transferring the resistance genes to the next generation. 
Effective resistance management depends on the early detection of the problem and rapid acquisition of information. To prevent or reduce the development of resistance to insecticides in cockroaches, an integrated pest management program should be used, in which chemical use should be minimized. It is necessary to have information about the source of resistance by conducting biochemical or molecular studies on resistant populations. The lethal effect of active substances should be increased by using synergistic substances. Insecticide applications should be made in more limited areas rather than large areas, and the same active substance should not be used for a long time. Insecticides with a different mode of action should be used in rotation, so resistance selection can be reduced. Biocidal products should be applied according to the label recommended doses, the use of higher may trigger resistance. In addition, new groups of insecticides (neonicotinoid and phenylpyrazole) which are non-persistent, fast-acting, environmentally-friendly should be used in the high resistance populations, and resistance levels should be checked periodically.

In conclusion, $P$. americana populations were found to be in the category of no resistance, very low resistance or low resistance to the tested chemicals while high resistance was found in all $B$. germanica populations except for permethrin and lambda-cyhalothrin in the Güllük population. As a result, inappropriate and extended use of synthetic pyrethroids may lead to high resistance in cockroaches. To prevent resistance to chemicals, the integrated pest management should be prioritized and chemical control should be kept at the lowest level. Also, insecticide resistance maps should be prepared by regularly monitoring the resistance of cockroach populations to insecticides used in a control program.

\section{Acknowledgments}

The authors are thankful to the Scientific Projects Administration Unit of Akdeniz University (Antalya, Turkey) (Project No: FDK-2015-410) for their financial support.

\section{References}

Azza, S. E. A., H. H. B. Nabil \& O. H. A. Yousif, 2010. Susceptibility of Periplaneta americana L. (Orthoptera: Blattidae) population from Wad medani (Sudan Gezira) to three public health insecticides. Resistant Pest Management Newsletter, 19 (2): 8-14.

Brogdon, W. G. \& J. C. McAllister, 1998. Insecticide resistance and vector control. Emerging Infectious Diseases, 4 (4): 605-613.

Cetin, H., O. Kocak, E. Oz, S. Koc, Y. Polat \& K. Arikan, 2019. Evaluation of some synthetic pyrethroids and piperonyl butoxide combinations against Turkish house fly (Musca domestica L.) populations. Pakistan Journal of Zoology, 51 (2): 703-707.

Chai, R. Y. \& C. Y. Lee, 2010. Insecticide resistance profiles and synergism in field populations of the German Cockroach (Dictyoptera: Blattellidae) from Singapore. Journal of Economic Entomology, 103 (2): 460-471.

Chang, K. S., E. H. Shin, J. S. Jung, C. Park \& Y. J. Ahn, 2010. Monitoring for insecticide resistance in field-collected populations of Blattella germanica (Blattaria: Blattellidae). Journal of Asia Pacific Entomology, 13 (4): 309-312.

Diaz Pantoja, C., M. G. Perez, E. Calvo, M. M. Rodriguez \& J. A. Bisset, 2000. Insecticide resistance studies on Blattella germanica (Dictyoptera: Blattellidae) from Cuba. Annals of New York Academy of Science, 916 (1): 628-634.

Doroudgar, A., H. Ladonni, R. Dehghani \& M. Sayah, 1998. Sensitivity of American cockroach to insecticides in Kashan hospitals. Feyz Journal of Kashan University of Medical Sciences, 2 (2): 89-94.

Erdogan, G. \& H. Cetin, 2020. Survey of deltamethrin resistance in house flies (Musca domestica L.) collected from Kumluca which is the most important greenhouse production area of Turkey. Fresenius Environment Bulletin, 29 (11): 10252-10256.

Erdogan, A. \& O. Kocak, 1989. Hamamböceği, Blattella germanica (L), popülasyonlarında nimf süresi ve ergin ömür uzunluğu ile ilgili araştırmalar. Hacettepe Üniversitesi Eğitim Fakültesi Dergisi, 4 (4): 235-238 (in Turkish with abstract in English). 
Fotedar, R. \& U. Banerjee, 1992. Nosocomial fungal infections - study of the possible role of cockroaches (Blattella germanica) as vectors. Acta Tropica, 50 (4): 339-343.

Garrett, D. A., J. S. Agee, E. R. Gremminger \& W. E. Morgan, 1968. Resistance levels of Izmir, Turkey bedbugs and cockroaches to insecticides 1966-67. Ft. Belvoir Defense Technical Information Center, Professional Report, No: 68-7.

Gondhalekar, A. D., C. Song \& E. Scharf, 2011. Development of strategies for monitoring indoxacarb and gel bait susceptibility in the German cockroach (Blattodea: Blattellidae). Pest Management Science, 67 (3): $262-270$.

Hu, I. H., S. M. Chen, C. Y. Lee \& K. B. Neoh, 2020. Insecticide resistance, and its effects on bait performance in fieldcollected German cockroaches (Blattodea: Ectobiidae) from Taiwan. Journal of Economic Entomology, 113 (3): 1389-1398.

Jang, C. W., Y. R. Ju \& K. S. Chang, 2017. Insecticide susceptibility of field-collected Blattella germanica (Blattaria: Blattalidae) in Busan, Republic of Korea during 2014. Entomological Research, 47 (4): 243-247.

Kawther, I. A., A. Abdalmagid, I. A. Elnaeim, A. E. Jamal, E. A. Hassan \& H. E. Ibrahim, 2013. Toxicity of permethrin $25 \%$ EC and diazinon $60 \%$ EC insecticides against American cockroach Periplaneta americana (L.) at Omdurman Locality hospitals, Khartoum State, Sudan 2012. Sudanese Journal of Public Health, 8 (3): 113-118.

Ladonni, H., 2001. Evaluation of three methods for detecting permethrin resistance in adult and nymphal Blattella germanica (Dictyoptera: Blattellidae). Journal of Economic Entomology, 94 (3): 694-697.

Lee, C. Y., L. C. Lee, B. H. Ang \& N. L. Chong, 1999. "Insecticide resistance in the Blattella germanica (L.) (Dictyoptera: Blattellidae) from hotels and restaurants in Malaysia, 171-182". Proceeding of the 3rd International Conference on Urban Pests (1999, Hronov, Czech Republic), Graficke Zavody, 678 pp.

Lee, C. Y., H. H. Yap, N. L. Chong \& R. S. T. Lee, 1996. Insecticide resistance and synergism in field collected German cockroaches (Dictyoptera: Blattellidae) in Peninsular Malaysia. Bulletin of Entomology Research, 86 (6): $675-$ 682.

Limoee, M., B. Davari \& S. H. Moosa-Kazemi, 2012. Toxicity of pyrethroid and organophosphorus insecticides against two field collected strains of the German cockroach Blattella germanica (Blattaria: Blattellidae). Journal of Arthropod Borne Diseases, 6 (2): 112-118.

Mallis, A., 1990. Handbook of Pest Control, 7th Ed. Franzak \& Foster Co., Cleveland, Ohio, 1152 pp.

Nasirian, H., H. Ladonnii, M. Shayeghi, H. Vatandoost, M. R. Yaghoobi-Ershadi, Y. Rassi, M. Abolhassani \& M. R. Abaei, 2006. Comparison of permethrin and fipronil toxicity against German cockroach (Dictyoptera: Blattellidae) strains. Iran Journal of Public Health, 35 (1): 63-67.

Pai, H. H., S. C. Wu \& E. L. Hsu, 2005. Insecticide resistance in German cockroaches (Blattella germanica) from hospitals and households in Taiwan. International Journal of Environmental Health Research, 15 (1): $33-40$.

Ser, Ö. \& H. Cetin, 2019. Investigation of susceptibility levels of Culex pipiens L. (Diptera: Culicidae) populations to synthetic pyrethroids in Antalya province of Turkey. Journal of Arthropod Borne Diseases, 13 (3): 243-258.

Silver, K. S., Y. Du, Y. Nomura, E. E. Oliveira, V. L. Salgado, B. S. Zhorov \& K. Dong, 2014. Voltage-gated sodium channels as insecticide targets. Advances in Insect Physiology, 46: 389-433.

Silverman, J. \& M. H. Ross, 1994. Behavioral resistance of field collected German cockroaches (Blattodea: Blattellidae) to baits containing glucose. Environmental Entomology, 23 (2): 425-430.

Strong, C. A., P. G. Koehler \& R. S. Patterson, 1997. Insecticide resistance decline and selection in laboratory-reared German cockroaches (Dictyoptera: Blattellidae). Journal of Economic Entomology, 90 (1): 183-187.

Syed, R., F. Manzoor, R. Adalat, A. Abdul-Sattar \& A. Syed, 2014. Laboratory evaluation of toxicity of insecticide formulations from different classes against American Cockroach (Dictyoptera: Blattidae). Journal of Arthropod Borne Diseases, 8 (1): 21-34.

Valles, M. V., 1999. $\lambda$-Cyhalothrin resistance detection in the German cockroach (Blattodea: Blattellidae). Journal of Economic Entomology, 92 (2): 293-297.

Valles, S. M. \& C. A. Strong, 2001. A microsomal esterase involved in cypermethrin resistance in the German cockroach, Blattella germanica. Pesticide Biochemistry and Physiology, 71 (1): 56-67. 
van den Bercken, J. \& H. P. M. Vijverberg, 1988. "Mode of Action of Pyrethroid Insecticides, 91-105". In: Recent Advances in Nervous System Toxicology (Eds. C. L. Galli, L. Manzo \& P. S. Spencer). NATO ASI Series (Series A: Life Sciences), Springer, Boston, MA Vol. 100, $391 \mathrm{pp}$.

Wahab, A. H., M. P. M. Tahir \& E. Mohamed, 2016. Pathogenic bacteria isolated from cockroaches found in food premises. Jurnal Teknologi, 78 (6-8): 73-77.

Wei, Y., A. G. Appel, W. J. Moar \& N. Liu, 2001. Pyrethroid resistance and cross-resistance in the German cockroach, Blattella germanica (L). Pest Management Science, 57 (11): 1055-1059.

WHO (World Health Organization), 1981. Instructions for determining the susceptibility or resistance of cockroaches to insecticides. Tentative instruction for determining the susceptibility or resistance of cockroaches to insecticides. WHO/VBC/75.593, $3 \mathrm{pp}$.

WHO (World Health Organization), 2006. Pesticides and their application for the control of vectors and pests of public health importance, $6^{\text {th }}$ Ed. World Health Organization. WHO/CDS/NTD/WHOPES/GCDPP/2006.1. WHO, Geneva, Switzerland. (Web page: https://apps.who.int/iris/handle/10665/69223) (Date accessed: May 2021).

WHO (World Health Organization), 2013. Test procedures for insecticide resistance monitoring in malaria vector mosquitoes. WHO press, Geneva, 30 pp. 